\title{
TARI MELINTING: SENI TARI TRADISIONAL LAMPUNG TIMUR
}

\author{
MELINTING DANCE: \\ TRADITIONAL DANCE ART OF EAST LAMPUNG
}

\author{
T. Dibyo Harsono \\ Balai Pelestarian Nilai Budaya Bandung \\ Jln. Cinambo No. 136 Ujungberung Bandung \\ e-mail: dibyoharsono@yahoo.com
}

\begin{abstract}
Abstrak
Salah satu kelengkapan dalam pelaksanaan tata cara adat, upacara adat yang ada pada masyarakat melinting adalah adanya sebuah tarian adat melinting. Pada awalnya tarian ini memang merupakan sebuah tarian sakral, namun dalam perkembangannya tarian ini banyak mengalami perubahan dan perkembangan, baik dalam segi gerak, kostum, maupun kesakralannya. Penelitian ini bertujuan mendeskripsikan dan mengungkap tari melinting beserta filosofi yang mendasarinya. Pengumpulan data dilakukan dengan melaksanakan wawancara mendalam, pengamatan (observasi), dan studi kepustakaan. Ternyata tari melinting memiliki makna yang mendalam, tidak hanya gerakan tarinya yang indah, namun juga filosofi yang ada di balik tarian tersebut, seperti tentang kearifan tradisional masyarakat, falsafah hidup, serta dinamika kehidupan masyarakat Melinting khususnya dan masyarakat Lampung Timur pada umumnya. Kata melinting mempunyai makna yang sangat luas, merupakan nama daerah (kecamatan), nama jenis tumbuhan, nama tarian, dan juga nama dari sebuah wilayah adat dari Keratuan Melinting yang meliputi daerah Labuhan Maringgai, Gunung Pelindung, Wana. Di masa lalu wilayah adat melinting mencakup daerah yang lebih luas lagi, ke utara sampai dengan pantai di Labuhan Maringgai dan ke selatan sampai ke daerah Tegineneng.
\end{abstract}

Kata kunci: melinting, sakral, tari.

\begin{abstract}
One of the complement during the ceremonial customs in Melinting society is Melinting dance. In the beginning, this dance is sacred, however during the time their movement, customs, or sacred has changed and developed. This research has a purpose to describe and reveal of Melinting dance with their philosophy. The procedure for collecting the data with an in depth interview, observation, and library research. In result, Melinting dance has a deep meaning. It is not only about beautiful dance movement, but also the philosophy of wisdom, life, also talking about the dynamics of melinting and East Lampung society. Word of Melinting has a broader meaning, such as name of an area (district), plantation, dancing, and the territory of Melinting crown including Labuan Maringgai, Gunung Pelindung, Wana. In the past, the melintingregion included a wider area, to the north reach Labuan Maringgau beach, and to the south reach Tegineneng area.
\end{abstract}

Keywords: Melinting, sacred, dance. 


\section{A.PENDAHULUAN}

Penelitian mengenai tari melinting ini diharapkan akan bisa menggambarkan serta melihat kehidupan masyarakat Melinting secara menyeluruh, dari sejarah Keratuan Melinting, tradisi atau adat kebiasaan masyarakat, dan kearifan tradisional masyarakat Melinting, yang mengambil lokasi di Desa Nibung, Kecamatan Gunung Pelindung, Kabupaten Lampung Timur.

Secara administratif Lampung Timur pada awalnya meliputi tiga wilayah yakni:

1. Wilayah Sukadana terdiri atas: Marga Sukadana, Marga Tiga, Marga Nuban, Marga Unyai Way Seputih.

2. Wilayah Labuhan Maringgai terdiri atas: Marga Melinting, Marga Sekampung Ilir, Marga Sekampung Udik, Marga Subing Labuhan.

3. Wilayah Gunung Sugih terdiri atas: Marga Unyai, Marga Subing, Marga Anak Tuha, Marga Pubian. Namun saat ini wilayah Gunung Sugih menjadi atau masuk wilayah Kabupaten Lampung Tengah.

Pada tahun 1946-1947, jumlah marga bertambah 2 yaitu Marga Terusan Unyai dan Marga Selagai Lingga. Hal ini terjadi karena adanya perubahan batas wilayah atau karena terjadinya perpindahan dan perkembangan penduduk.

Keputusan Bupati Lampung Timur No. 19 tahun 2001 dan No. 6 tahun 2002, jumlah desa di Kabupaten Lampung Timur berjumlah 232 desa definitif dan desa persiapan. Setelah keluar Keputusan Bupati Lampung Timur No. 13 tahun 2003, tanggal 10 Desember 2003 tentang perubahan status dan desa menjadi kelurahan, maka 5 desa yang berada di Kecamatan Sukadana menjadi kelurahan yakni: Pasar Sukadana, Sukadana Ilir, Negara Nabung, Sukadana, dan Mataram Marga. Saat ini jumlah desa yang ada di Lampung Timur ada 241 desa terdiri atas 227 desa definitif, 5 kelurahan, 9 desa persiapan. Sementara itu kecamatan yang ada di Lampung Timur berjumlah 23 kecamatan yakni:

1. Kecamatan Metro Kibang dengan ibukota Margototo, membawahi 6 desa.

2. Kecamatan Batang Hari dengan ibukota Banar Joyo, membawahi 16 desa.

3. Kecamatan Sekampung dengan ibukota Sumber Gede, membawahi 14 desa.

4. Kecamatan Marga Tiga dengan ibukota Tanjung Harapan, membawahi 13 desa.

5. Kecamatan Sekampung Udik dengan ibukota Pugung Raharjo, membawahi 14 desa.

6. Kecamatan Jabung dengan ibukota Negara Batin, membawahi 19 desa.

7. Kecamatan Waway Karya dengan ibukota Sumberrejo, membawahi 9 desa.

8. Kecamatan Pasir Sakti dengan ibukota Mulyo Sari, membawahi 8 desa.

9. Kecamatan Labuhan Maringgai dengan ibukota Labuhan Maringgai, membawahi 11 desa.

10. Kecamatan Gunung Pelindung dengan ibukota Negeri Agung, membawahi 5 desa.

11. Kecamatan Melinting dengan ibukota Wana, membawahi 6 desa.

12. Kecamatan Mataram Baru dengan ibukota Mataram Baru, membawahi 7 desa.

13. Kecamatan Bandar Sribhawono dengan ibukota Sribhawono, membawahi 6 desa.

14. Kecamatan Way Jepara dengan ibukota Braja Sakti, membawahi 13 desa.

15. Kecamatan Braja Selebah dengan ibukota Braja Harjosari, membawahi 6 desa.

16. Kecamatan Labuhanratu dengan ibukota Labuhan Ratu, membawahi 9 desa.

17. Kecamatan Sukadana dengan ibukota Sukadana, membawahi 16 desa. 
18. Kecamatan Bumi Agung dengan ibukota Donomulyo, membawahi 6 desa.

19. Kecamatan Batanghari Nuban dengan ibukota Sukaraja Nuban, membawahi 13 desa.

20. Kecamatan Pekalongan dengan ibukota Pekalongan, membawahi 10 desa.

21. Kecamatan Raman Utara dengan ibukota Kota Raman, membawahi 11 desa.

22. Kecamatan Purbolinggo dengan ibukota Taman Fajar, membawahi 12 desa.

23. Kecamatan Way Bungur dengan ibukota Tambah Subur, membawahi 8 desa.

Menurut Kitab Kuntara Raja Niti (dari Lampung Timur milik Bapak Rizal Ismail), keratuan (kekuasaan/wilayah adat) di tanah Lampung ada empat:

1. Ratu Di Pugung.

2. Ratu Di Puncak, orang Abung Marga Nunyai.

3. Ratu Pemanggilan, Marga Anak Tuha.

4. Ratu Di Balau Marga Pubian.

Kata melinting tidak hanya nama sebuah daerah secara administratif, juga merupakan nama sebuah tarian tradisional dari Lampung Timur, namun kata melinting juga merupakan wilayah adat dari Keratuan Melinting yang wilayahnya lebih luas dari sekadar wilayah administratif tadi. Wilayah adat Keratuan Melinting meliputi daerah Labuhan Maringgai, Wana, Gunung Pelindung, di sebelah utara sampai ke pesisir, dahulunya ke selatan sampai ke daerah Tegineneng. Pimpinan Keratuan Melinting saat ini dipegang Bapak Rizal Ismail, SE, MM yang bergelar Sultan Ratu Idil Muhammad Tihang Igama IV, beliau saat ini berdiam di Desa Nibung, Kecamatan Gunung Pelindung, Lampung Timur. Kebetulan beliau juga sebagai pengelola Sanggar Melinting yang tahun 2012 mendapatkan bantuan sosial dari Kemendikbud, yang dimanfaatkan untuk memugar sanggar tersebut.

\section{B. METODE PENELITIAN}

Penelitian ini bersifat deskriptif, sedangkan pengumpulan data dilaksanakan melalui wawancara mendalam, pengamatan (observasi), dan studi kepustakaan. Wawancara mendalam (depth interview) dilaksanakan kepada para informan yang benar-benar menguasai perihal tari melinting dan sejarahnya yang ada di lokasi penelitian dan lokasi lain (seperti Taman Budaya di Bandar Lampung). Sementara itu pengamatan dilakukan di lokasi penelitian khususnya di Sanggar Melinting milik Bapak Rizal Ismail yang merupakan pimpinan adat, dan masyarakat Desa Nibung, Kecamatan Gunung Pelindung. Studi kepustakaan dilakukan dengan mencari acuan atau buku, literatur yang berkaitan dengan seni tari melinting, salah satunya dari naskah lama (Kuntara Raja Niti) milik Keratuan Melinting.

\section{HASIL DAN BAHASAN \\ 1. Sejarah Keturunan Ratu Melinting}

Asal-usul orang Lampung salah satunya disebutkan berasal dari dataran tinggi Sekala Brak di lereng Gunung Pesagi, Lampung Barat. Kemudian mereka menyebar membentuk keratuan yakni Keratuan Di Puncak, Keratuan Di Balau, dan Keratuan Di Pugung, yang masingmasing memiliki wilayah adat sesuai dengan namanya. Dari Keratuan Di Pugung inilah selanjutnya menurunkan Ratu Darah Putih yang ada di Kampung Meringgai Marga Melinting. Untuk mengetahui asal-usul keturunan Ratu Melinting ada keterkaitan Keratuan Di Pugung dan Kesultanan Banten. Keratuan Di Pugung tempat yang saat ini menjadi Taman Purbakala Pugung Raharjo, Desa Pugung Raharjo, Kecamatan Sekampung Udik, Lampung Timur. Informasi dari para pemuka adat setempat bahwa Desa Pugung Raharjo tadinya merupakan suatu kerajaan yang dipimpin oleh seorang raja yang bernama Ratu Di Pugung. Kata Pugung Raharjo mempunyai 2 suku kata yakni Pugung merupakan nama yang sudah ada terlebih dahulu, yang menurut bahasa 
daerah setempat berarti "tempat yang tinggi", dan Raharjo merupakan kata yang ditambahkan setelah datangnya para transmigran di daerah tersebut yang bermakna "subur".

Berdasarkan keterangan Ratu Di Pugung mengacu dari buku turunan Ratu Darah Putih yang ada di Kampung Meringgai Marga Melinting, dalam aksara Lampung yang diterjemahkan oleh Sultan Ratu Idil Muhammad Tihang Igama IV, antara lain berisi silsilah keturunan para penguasa Melinting:

"Ini asal Ratu Di Pugung namanya Ratu Galuh kampungnya suku Apus, waktu Ratu Empat bebagi tanah di Sekala Brak, dia pulang laju pindah di Pugung ialah nama Ratu Di Pugung. Tempat Pugung itu di antara Gunung Sugih Besar sama Bujung. Ratu Pugung ada putra nama Minak Sang Bare Masakti, Minak Sang Bare Masakti Materaken Minak Riyo Puhawang, Minak Riyo Puhawang Materaken Temenggung Kalelatun Temenggung Kalelatun puteranya dua, satu Dapati Lebuh Kaca dua Minak Riyo Jalan yang muda. Maka Temenggung Kalelatun dan anak istri, kaum dan rakyatnya dibawa pindah dari Pugung ke Sarekulo yang dekat Kampong Negara Saka sekarang. Dipati Lebuh Kaca ada putera dua anak satu laki-laki dan satu perempuan anak yang laki-laki bernama Patibi Lanagiri dan yang perempuan bernama Puteri Kandang Rarang, Minak Riyo Jalan puteranya satu Puteri Sinar Alam".

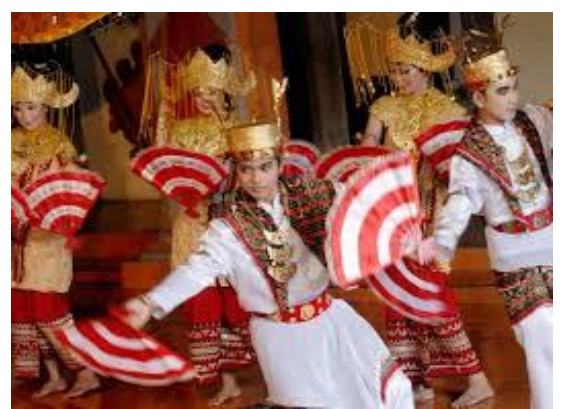

Gambar 1.Tari Melinting.

Sumber: www.IndonesiaTourism.com.

\section{Sejarah Tari Melinting}

Kesenian merupakan salah satu perwujudan kebudayaan. Beragam jenis kesenian ada di Indonesia dan itu merupakan salah satu aset bangsa yang pantas dijaga dan dilestarikan keberadaannya. Seperti halnya di Provinsi Lampung juga memiliki beragam kesenian termasuk seni tari tradisional yang tersebar di seluruh kabupaten. Salah satu jenis seni tari tersebut adalah seni tari melinting yang berada di daerah Melinting, Labuhan Meringgai, Kabupaten Lampung Timur. Seni tari melinting merupakan salah satu tari tradisional Lampung klasik, karena tarian ini sudah mengalami perjalanan sejarah yang cukup panjang, semenjak masuknya agama Islam ke Indonesia. Perkembangan tari melinting saat ini masih belum dikenal luas oleh masyarakat Indonesia, baik yang ada di Provinsi Lampung maupun yang ada di luar Lampung. Untuk itulah perlu adanya sosialisasi yang gencar melalui berbagai media yang ada.

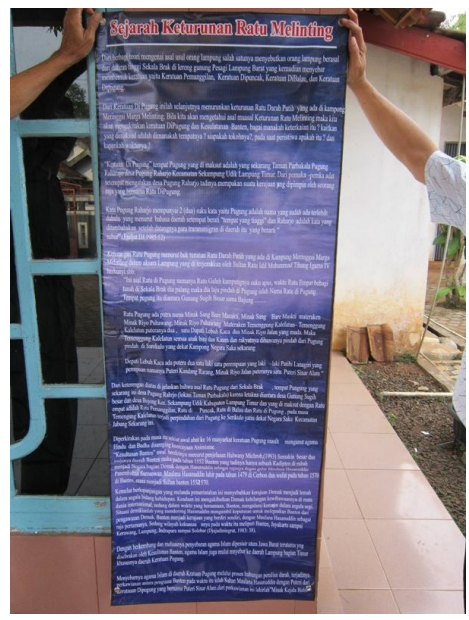

Gambar 2. Informasi mengenai Sejarah singkat Keratuan Melinting. Sumber: dokumentasi pribadi.

Pada abad ke-16 yakni masa Keratuan Melinting di bawah Panembahan Mas, pengaruh agama Islam mulai mendominasi tata gerak maupun kostum tari melinting. Sejauh ini belum diperoleh 
kejelasan atau kepastian dari kata melinting, namun ada sementara pendapat yang mengatakan bahwa melinting berasal dari kata melitting dengan penjelasan sebagai berikut: ayahanda Pangeran Panembahan Mas bergelar Minak Kejala Biddin dan saudaranya yang bergelar Minak Kejala Ratu mengirim kabar kepada orang tuanya, yakni Sultan Maulana Hasanuddin, yang masih berada di Banten. Mereka meminta pertolongan karena kampung mereka sering didatangi perampok. Oleh Sultan Banten, dikirimlah "petunggu batang" berupa bibit tumbuhtumbuhan untuk menjaga serangan rampok. yaitu bibit jati, bibit melaka (petai cina), burung kepala putih dan katangkatang.

Ketika bibit pohon jati ditanam di sela-selanya tumbuh alang-alang dan batang melinting. Oleh kedua putra Sultan Banten tersebut, daerah itu kemudian dinamakan daerah Melinting, nama yang digunakan sampai saat ini. Ratu yang berkuasa di daerah itu juga kemudian digelari Ratu Melinting.

Suatu ketika, Sang Ratu menciptakan satu tarian yang sangat indah dan sakral. Tarian itu hanya bisa dimainkan di lingkungan istana, dan bukan karya biasa. Namanya kemudian dikenal sebagai tari melinting. Tari ini sudah mengalami perjalanan sejarah yang cukup lama, yakni sejak masuknya agama Islam ke Indonesia. Akan tetapi dalam perkembangannnya sekarang, tari melinting belum banyak dikenal oleh masyarakat, baik di daerah Lampung sendiri maupun masyarakat Nusantara.

Melinting berasal dari kata meninting yang memiliki makna membawa, munculnya kata atau istilah meninting bersamaan dengan masa penyebaran agama Islam. Sehingga dari kata meninting tersebut dapat disimpulkan adalah membawa misi Islam. Keratuan Darah Putih yang bermukim di Meringgai atau Keratuan Melinting pada saat ini memiliki wilayah adat, antara lain: Desa Meringgai, Tanjung Aji, Tebing, Wana,
Nibung, Pempen, dan Negeri Agung, Kabupaten Lampung Timur.

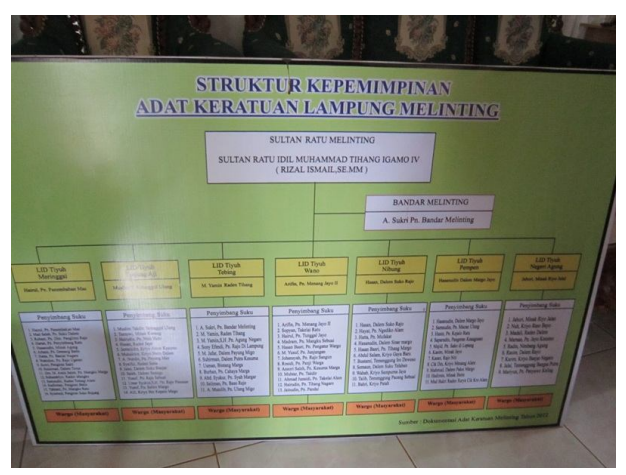

Gambar 3. Struktur kepemimpinan Keratuan Melinting.

Sumber: Dokumentasi pribadi.

Menurut keterangan Fuzie Saleh Pengeran Bandar Nata Negara (2011), tokoh adat Melinting, nama tari melinting berkaitan dengan asal-usul tari yang berasal dari daerah Melinting, yang sejak dulu (zaman Belanda) tarian ini sudah dikenal orang dan belum ada satu daerah pun yang mengaku memiliki tarian ini. Hal itu disebabkan setiap daerah di Lampung memiliki tariannya masing-masing, seperti halnya di Marga Sekampung, memiliki tarian yang dikenal dengan nama tari sekampung.

Menurut keterangan Budiman Raden Kesuma Yuda (2011), keturunan Ratu Darah Putih yang bertempat tinggal di Kahuripan, Kalianda, Lampung Selatan, menyatakan bahwa tari melinting memang berasal dari daerah Melinting, Lampung Timur. Sementara itu tarian yang ada di Keratuan Darah Putih adalah tari tupping atau tari topeng.

Menurut keterangan Zubir Pengeran Kesuma Ratu (2011), Bandar Marga Sekampung Udik yang berdomisili di Desa Gunung Raya, Kecamatan Sekampung Udik, Lampung Timur, tari melinting telah ada semenjak dahulu kala dan asli peninggalan Ratu Melinting, namun pencipta tarian ini oleh Ratu Melinting 
yang keberapa belum diketahui dengan pasti.

Tari melinting ada beberapa macam yaitu tari: bejeneng, sabai, cetik cak embung, cetik kipas, sebai, semani. Sementara itu tari kreasi baru melinting yang sering dipentaskan dan kita kenal saat ini nama aslinya adalah tari cetik kipas, tarian inilah yang akan kita angkat dalam kajian ini, karena sampai saat ini tarian tersebut yang masih tetap eksis dan dikenal secara luas.

\section{Tari Cetik Kipas M elinting}

Tari melinting yang kita kenal sekarang ini merupakan peninggalan dari Ratu Melinting, diperkirakan telah ada pada abad ke-16, berarti pada masa Ratu Melinting yang pertama yakni Minak Kejala Bidin atau putranya yakni Pengeran Panembahan Mas, atau putranya yakni Minak Yuda Resmi, karena sampai saat ini belum ada data resmi dan pasti pada masa Ratu Melinting yang keberapa tarian ini diciptakan.

Tari cetik kipas merupakan tarian adat yang dilaksanakan pada acara adat (begawi), pada saat menyambut tamu agung, sementara itu penarinya adalah kerabat atau keluarga ratu atau bangsawan Melinting. Perkembangan tari melinting semenjak disempurnakan pada tahun 1958, kemudian namanya menjadi tari melinting gaya baru. Perkembangan yang terjadi sekarang merupakan perubahan yang agak jauh dari bentuk aslinya baik pada gerak, busana, maupun aksesorinya. Deskripsi lebih lengkap ada di bagian bawah pada uraian mengenai tarian melinting.

\section{Sistem Kesukuan (adat) Melinting}

Desa Nibung, Kecamatan Gunung Pelindung berpenduduk $40 \%$ merupakan orang Lampung asli beradat melinting, yang memiliki kitab hukum adat Kuntara Raja Niti berisikan 67 pasal. Kitab ini ditetapkan pada saat diadakan pertemuan atau musyawarah dengan Sultan Ratu Idil Muhammad Tihang Igama, pada tahun 1336. Adapun kesepakatan tersebut dilaksanakan oleh marga: Meringgai, Tanjung Aji, Tebing, Wana, Nibung, Pempen, Negeri Agung (dikutip dari buku Ratu Melinting: Adat Istiadat Lampung Melinting, tahun 1988). Dewasa ini Keratuan Melinting (Dalem Ratu Melinting) dalam silsilah merupakan keturunan ke-15 dari Keratuan Melinting sebagai Penyimbang Suku di Desa Meringgai.

\section{Sistem Kepercayaan}

Sebagian besar penduduk di Kecamatan Meringgai, Gunung Pelindung dan Kabupaten Lampung Timur pada umumnya memeluk agama Islam, namun tidak bisa disangkal bahwa kepercayaan penduduk yang mereka warisi dari leluhur mereka masih tetap melekat, meskipun sudah banyak berkurang. Kepercayaan yang masih dianut penduduk antara lain: penyalaan dupa/kemenyan dengan memercikkan air yang telah direndami beragam bunga di sekitar lokasi acara, pada penyelenggaraan apacara adat atau pergelaran kesenian seperti pertunjukan tari melinting ini. Kemudian mengheningkan cipta sebagai upaya memohon izin kepada pencipta tari melinting untuk dipentaskan, dan agar pementasannya berjalan lancar.

Memberikan usapan dengan air embun ke perangkat peralatan musik talo balak dan wajah para penari. Menurut kepercayaan secara turun temurun ketiga hal tadi harus dilaksanakan, sebab apabila hal tersebut dilanggar atau tidak dilaksanakan maka akan muncul kejadian yang tidak diinginkan seperti penari mendadak pingsan, mendadak sakit, dan pementasan tari tidak menarik dilihat. Akibat pelanggaran tersebut mereka rasakan saat mereka tidak melaksanakan hal di atas, yakni saat penyelenggaraan acara Jakarta Fair tahun 1990. Dari sekitar 200 orang personil tim kesenian, 22 orang jatuh pingsan. Kemudian pada tahun 1982 hal tersebut juga dialami oleh seorang penari saat mengisi acara Duta Seni Kelima di Kota Padang, Sumatera Barat. Pendapat lain akibat dari mengabaikan hal tersebut di 
atas adalah pementasan dirasakan kurang menarik, kurang memikat, baik dari penarinya maupun dari segi musik pengiringnya.

\section{Fungsi Tari Melinting}

Pada tahun 1958 sebelum mengalami perkembangan dan penyempurnaan tari melinting merupakan tarian yang hanya dilakukan oleh keluarga Ratu Melinting, dan hanya dipentaskan saat ada acara gawi adat (keagungan Keratuan Melinting) saja. Sementara itu penarinya adalah para putra dan putri Ratu Melinting, dengan tempat pementasannya di sessat atau balai adat. Seiring dengan perkembangan zaman, tari melinting, banyak mengalami pergeseran fungsi, dari sebuah tarian sakral menjadi sebuah tarian hiburan dan tarian untuk menyambut tamu agung yang datang ke daerah Lampung. Pada abad ke-16 bertepatan dengan masa Pangeran Panembahan Mas, Keratuan Melinting, pengaruh persebaran agama Islam mulai menguasai segala bentuk tata cara kehidupan masyarakat di wilayah Keratuan Melinting. Demikian pula pengaruh pada tarian khususnya tari melinting, seperti pengaruh dalam hal pakaian atau kostum. Demikian pula peralatan pengiringnya. Musik pengiring tari melinting memiliki alat musik yang khas dan baku, serta ditabuh atau dimainkan dengan aturan tidak sembarangan atau asal-asalan. Adapun jenis peralatan pengiring tersebut adalah sebagai berikut: tabuh arus, tabuh cetik, dan tabuh kedanggung.

Menurut Agus Gunawan dari Sanggar Rumah tari sangisu Bandar Lampung yang belum lama ini melakukan penelitian asal-usul tari melinting di Lampung Timur, fungsi tari melinting sudah banyak berubah, tidak seperti pertama kali diciptakan oleh Ratu Melinting. Ia memaparkan, tari melinting sebelum mengalami perkembangan penyempurnaan adalah mutlak sebagai tarian keluarga Ratu Melinting yang dipergelarkan hanya pada saat acara gawi adat Keagungan Keratuan Melinting. Para penarinya hanya terbatas dimainkan oleh putra dan putri Ratu Melinting sendiri. Pagelarannya dilakukan di Sessat atau Balai Adat.

Tari melinting yang dikembangkan kembali sejak 1958, tidak lagi merujuk sepenuhnya pada bentuk aslinya, baik gerak, busana, dan aksesoris. Telah terjadi modifikasi di sana-sini. Dari segi fungsi pun, persembahan tari melinting telah bergeser dari peragaan sakral menjadi tarian hiburan lepas atau paling tidak menjadi persembahan pada tamu agung yang berkunjung ke Lampung.

Sejak mengalami pergeseran fungsi, busana tari yang dipakai pun berubah agak jauh dari bentuk dan warna aslinya. Dulu penari melinting putra memakai kopiah emas melinting, baju dan jung sarat yang diselempangkan, baju teluk belanga, kain tuppal disarungkan, kipas warna merah, bulu seretei, sesapur handak putih, bunga pandan, dan celana panjang putih. Sekarang, penari putra memakai kopiah emas pepadun, baju teluk belanga, kain tapis, kipas warna bebas, dan bulu seretei.

\section{Busana dan Aksesori Tari Melinting}

Tari melinting semenjak mengalami perkembangan dan pergeseran fungsi, kemudian berpengaruh juga pada kostum yang dipakai, karena perubahannya cukup berbeda dari sebelumnya. Misalnya saja pada busana dan aksesori penari putra: 
Tabel 1. Busana dan Aksesori Penari Putra

\begin{tabular}{cll}
\hline No. & \multicolumn{1}{c}{ Dahulu } & \multicolumn{1}{c}{ Sekarang } \\
\hline 1. & Kopiah emas melinting & Kopiah emas pepadun \\
2. & Jung sarat diselempangkan & \\
& /tidak pakai baju & Baju teluk belanga \\
3. & Baju teluk belanga & Kain tapis \\
4. & Kain tuppal disarungkan & Kipas warna bebas \\
5. & Kipas warna merah & Bulu seretei \\
6. & Bulu seretei & \\
7. & Sesapur handak putih & \\
8. & Bunga pandan & \\
9. & Celana panjang putih & \\
\hline
\end{tabular}

Dari tabel di atas terlihat bahwa dalam perkembangannya tari melinting khususnya yang berkaitan dengan busana serta aksesori pada penari putra mengalami banyak pengurangan, terlihat lebih praktis.
Hal ini mengingat perkembangan zaman yang menuntut segala sesuatunya lebih ringkas, lebih simpel. Namun tidak menghilangkan ciri khas Lampung, yakni dengan adanya kain tapis.

\section{Tabel 2. Busana dan Aksesori Penari Putri}

\begin{tabular}{cll}
\hline No. & \multicolumn{1}{c}{ Dahulu } & \multicolumn{1}{c}{ Sekarang } \\
\hline 1. & $\begin{array}{l}\text { Siger melinting cadar warna } \\
\text { merah/putih }\end{array}$ & Siger melinting cadar kuningan \\
2. & Kebaya putih tanpa lengan & Kebaya putih lengan panjang \\
3. & Tapis melinting & Tapis pepadun \\
4. & Rambut cemara panjang & Rambut disanggul \\
5. & Kipas warna putih & Kipas warna bebas \\
6. & Gelang ruwi & Gelang ruwi \\
7. & Gelang kano & Buah jukum \\
\hline
\end{tabular}

Tabel di atas memperlihatkan adanya perubahan pada busana dan aksesori penari putri, ada yang terlihat lebih sederhana. Untuk penari putri tetap lengkap busananya, karena semua aksesori tersebut merupakan identitas Lampung seperti kain tapis, siger melinting.

Untuk busana dan aksesoris penari putri, tari melinting lama menggunakan siger melinting cadar warna merah/putih, kebaya putih tanpa lengan, tapis melinting, rambut cemara panjang, kipas warna putih, gelang ruwi dan gelang kano. Sekarang pakaian dan aksesori itu diganti dengan siger melinting cakar kuningan, kebaya putih lengan panjang, tapis pepadun, rambut disanggul, kipas warna bebas, gelang ruwi dan buah jukum. 


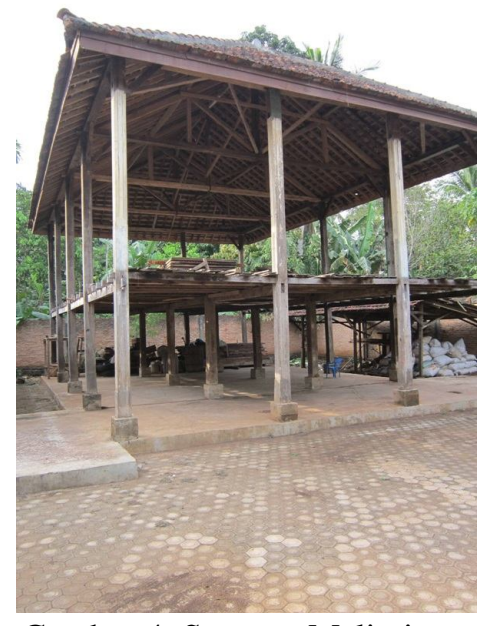

Gambar 4. Sanggar Melinting sebelum dipugar.

Sumber: Dokumentasi pribadi.

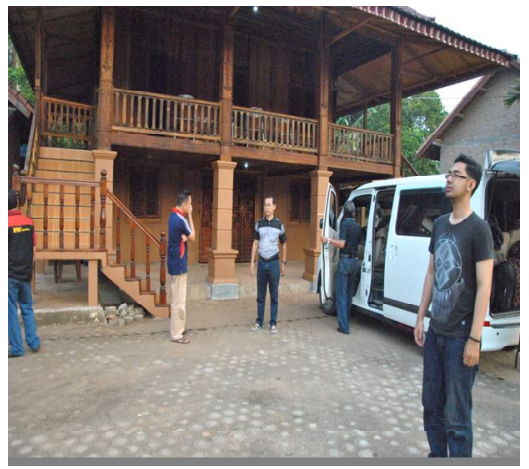

Gambar 5. Sanggar Melinting sesudah Dipugar.

Sumber: Dokumentasi pribadi.

Meskipun pada awalnya sarana untuk latihan tari melinting kurang memadai seperti nampak dalam foto di atas, namun kegiatan kesenian tersebut tetap berlangsung. Apalagi setelah adanya pemugaran sanggar, sehingga tempat tersebut sangat representatif untuk tempat berlatih tari, dan kegiatan berkesenian semakin baik.

\section{Musik Pengiring}

Musik atau iringan, unsur iringan (musik) dalam tari bukan hanya sekadar iringan, karena musik merupakan pasangan yang tidak dapat ditinggalkan/dipisahkan. Oleh karena itu musik yang dipergunakan untuk mengiringi tari harus digarap betulbetul sesuai dengan garapan tarinya. Dalam hubungannya dengan seni tari, pada umumnya iringan berfungsi sebagai penguat atau pembentuk suasana. Iringan dibagi dua macam, yaitu musik internal dan musik eksternal. Musik internal adalah musik yang bersumber dari diri penari, misalnya suara yang ditimbulkan dari tepukan tangan, vokal penari, dan hentakan kaki penari. Adapun musik eksternal adalah musik yang berasal dari alat musik instrumental, misalnya piano, gitar, dan gamelan.

Fungsi musik ada tiga, yaitu sebagai pengiring, pemberi suasana, dan ilustrasi. Sebagai pengiring tari, berarti peranan musik hanya mengiringi atau menunjang penampilan tari. Fungsi musik sebagai pemberi suasana berarti musik dipakai untuk membantu suasana adegan dalam tari. Sementara fungsi musik ilustrasi hanya berfungsi sebagai pengiring.

Iringan pada tari melinting adalah iringan atau musik eksternal nama seperangkat instrumen yang digunakan adalan talo balak (kelittang). Jenis tabuhan yang digunakan adalah tabuh harus pada adegan pembukaan, tabuh cetik pada adegan punggawo ratu, tabuh kedangdung pada adegan mulai batangan, tabuh kedangdung pada adegan kenui melayang, dan tabuh arus pada adegan penutup.

\section{Gerak Tari}

Gerak tari merupakan unsur terpenting dan utama dari sebuah tarian, gerakan di dalam sebuah tarian bukanlah sebuah gerak yang realistis, melainkan gerak yang telah diberi sentuhan bentuk ekspresif dan estetis.

Gerak tari selalu melibatkan unsur anggota badan manusia, gerak dalam tari berfungsi sebagai media untuk mengkomunikasikan maksud atau tujuan tertentu. 
Gerak dalam sebuah tarian membutuhkan suatu proses pengolahan atau penggarapan terlebih dahulu, penggarapan tersebut bersifat dinamis. Gerak-gerak tarian yang telah mendapatkan sentuhan atau mengalami proses penghalusan yang mengarah pada gerakan-gerakan atau bentuk yang indah. Pengolahan gerak tari melalui proses perubahan atau perombakan dari gerak aslinya, hal tersebut merupakan salah satu dari proses perkembangan tari melinting. Proses yang dilalui lewat pengolahan tersebut memunculkan dua jenis gerakan tari, yakni berupa gerak murni dan gerak maknawi.

Gerak murni yaitu merupakan gerak yang mempunyai nilai artistik dan tidak ditujukan atau dimaksudkan untuk menggambarkan sesuatu, namun yang diutamakan adalah keindahan gerak tarian. Gerak maknawi yakni merupakan gerak yang telah mendapatkan variasi atau perubahan, diubah menjadi sebuah gerak tari yang indah dan memiliki atau mengandung makna.

Gerak maknawi ini dalam proses pengolahannya mengandung suatu pengertian atau maksud tertentu, di samping keindahan geraknya. Gerak maknawi disebut juga dengan istilah gerak gesture, bersifat menirukan (imitatif dan mimitif). Gerak imitatif merupakan gerak peniruan dari beragam gerak binatang maupun alam (flora dan fauna). Gerak mimitif merupakan gerak peniruan yang diambil dari gerak-gerik manusia. Salah satu kesenian tradisional yang hidup di Melinting (Kecamatan Labuhan Meringgai), Desa Nibung (Kecamatan Gunung Pelindung), adalah tari melinting. Di lihat dari sejarahnya, tarian ini merupakan tari adat tradisional Keagungan Keratuan Melinting yang diciptakan oleh Ratu Melinting (Ratu Melinting yang keberapa belum diketahui secara pasti) yang dipentaskan pada saat acara gawi adat (begawi).

Fungsi tari melinting dahulu merupakan tarian Keluarga Ratu Melinting dan hanya dipentaskan oleh Keluarga Ratu saja di tempat yang tertutup (sessat atau balai adat), tidak boleh diperagakan oleh sembarang orang. Pementasannya pun hanya pada saat gawi adat Keagungan Keratuan Melinting saja. Personal penarinya pun hanya sebatas pada putra-putri Ratu Melinting.

Namun, dalam perkembangannya sekarang tari melinting tidak lagi mutlak sebagai tarian keluarga Ratu Melinting dan tidak lagi berfungsi sebagai tari upacara tetapi sudah bergeser menjadi tari pertunjukan atau tontonan pada saat penyambutan tamu-tamu agung yang datang ke daerah Lampung serta acara-acara besar lainnya seperti acara kesenian Lampung, Festival Tari, dan lain-lain. Baru-baru ini yaitu pada Bulan April 2007 yang lalu tari melinting dipentaskan secara masal, terdiri atas 25 pasang penari dalam upacara penutupan Musyabaqoh Tilawatil Quran tingkat Provinsi Lampung yang dilaksanakan di Pusat Kegiatan Olah Raga Way Halim Bandar Lampung. Hal ini berarti juga bahwa tari melinting sudah tersebar luas di Provinsi Lampung.

Menurut bentuk geraknya terdapat dua jenis gerak, yaitu gerak murni dan gerak maknawi. Gerak murni adalah gerak yang digarap sekadar untuk mendapatkan bentuk artistik dan tidak dimaksudkan untuk menggambarkan sesuatu. Gerak maknawi adalah gerak yang mengandung arti yang jelas dan sudah mengalami pengolahan. Gerak murni banyak digunakan dalam garapan tari yang nonrepresentasional, sedangkan gerakan maknawi banyak terdapat dalam garapan tari yang representasional, namun dengan tidak menutup kemungkinan masuknya gerak murni.

Gerak dalam tari melinting adalah gerak maknawi, yaitu setiap gerakan mempunyai maksud atau makna. Pada adegan pembukaan, makna gerak adalah bahwa putra dan putri punyimbang melakukan penghormatan kepada para punyimbang/tamu agung.

Pada adegan kugawo Ratu, makna gerak adalah melam-bangkan keperkasaan putra-putri punyim-bang. Pada adegan 
kenui melayang, keagungan dan kelemahlembutan punyim-bang merupakan ungkapan keleluasaan berpendapat/bersikap. Pada adegan penutup, makna gerak adalah bahwa putra putri punyimbang memberi penghormatan kepada punyimbang.

Gerakan yang dipakai pada tari melinting dibedakan antara gerakan penari putera dan puteri meliputi : babar kipas, jong sumbah, sukhung, sekapan balik palau, kenui melayang nyiduk, salaman, suali, niti batang, luncat kijang, dan lapah ayun.

Gerak penari putri meliputi babar kipas, jong sumbah, sukhung, sekapan, timbangan / terpipih mabel melayang, ngiyau bias, nginjak lado, nginjak tahi manuk, lapah ayun.

\section{Tata rias}

Tata rias adalah seni menggunakan bahan-bahan kosmetik untuk mewujudkan wajah peranan. Fungsi rias adalah memberikan bantuan dengan jalan memberikan dandanan atau perubahan pada pemain hingga berbentuk suasana yang cocok dan wajar.

Bagi seorang penari, rias merupakan hal yang sangat penting. Pemakaian tata rias yang digunakan untuk pertunjukan akan berbeda dengan tata rias sehari-hari. Tata rias yang dipakai sehari-hari pemakaiannya cukup tipis dan tidak memerlukan garis-garis kuat pada bagian wajah.

Sementara untuk tata rias pertunjukan tari, segala sesuatu diharapkan lebih jelas dan lebih tebal. Hal ini penting sekali dalam pertunjukan tari, karena untuk memperkuat garis-garis ekspresi dan menambah daya tarik penampilan. Tata rias merupakan hal penting dalam pertunjukan tari karena membantu penari untuk membedakan karakter.

Tata rias yang digunakan penari putri dalam tari melinting adalah rias cantik. Pada prinsipnya rias wajah pada tari melinting adalah untuk membuat wajah cerah dan terlihat cantik, sementara untuk penari putra hanya menggunakan bedak untuk alas dari rias wajah. Tata rias pada penari melinting pada intinya adalah memberikan kesan menggembirakan, menyenangkan, tidak ada kesan sedih, karena tarian ini adalah tarian kegembiraan.

\section{Tata busana}

Busana tari tidak sama dengan pakaian sehari-hari. Fungsi fisik busana adalah sebagai penutup dan pelindung tubuh, sedangkan fungsi artistiknya merupakan unsur keindahan dan keserasian bagi tubuh penari.

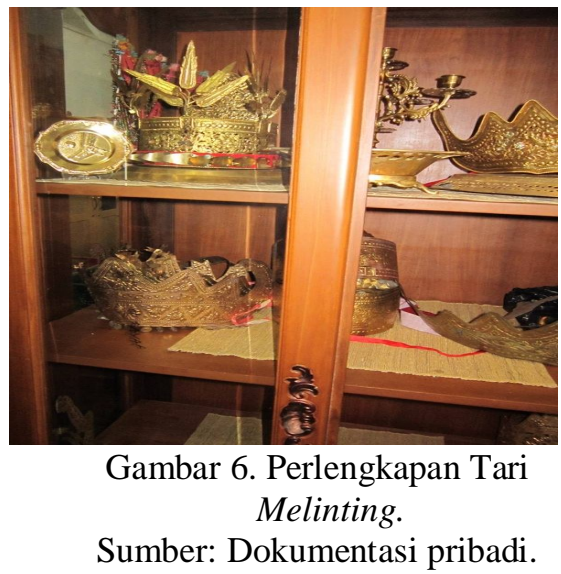

Fungsi busana juga tidak jauh berbeda dengan tata rias, yaitu mendukung tema atas isi dan memperjelas peranan-peranan dalam suatu sajian tari. Dalam perkembangannya, pakaian tari telah disesuaikan dengan kebutuhan tari tersebut.

Busana tari yang baik tidak hanya sekadar untuk menutup tubuh semata, melainkan juga harus dapat mendukung penampilan tari. Busana tari dipergunakan untuk melukis-kan sesuatu oleh penciptanya dan dipakai oleh penarinya serta tidak terlepas dari pemilihan nilai terhadap warna, garis dan bentuk. Maka, tata busana selain untuk memperkuat peranan, pemilihan warna, garis dan bentuk, juga bisa mendalami kejiwaan seni tari, serta akan memberi suasana yang dimaksudkan. 
Dalam tari melinting, busana yang digunakan penari putri adalah siger bercadar bunga pandan subang, kalung buah jukum, gelang kano, bulu seretei, gelang ruwi sesapur handak, tapis, dan jungsarat. Adapun busana penari putra adalah kopiah emas, kembang melur bunga pandan, buah jukum, jungsarat, papan jajar, bulu seretei, sesapur handak, sinjang tuppal, celana teluk belanga, baju tanpa lengan tanpa aksesoris.

Siger merupakan tutup kepala khususnya bagi penari wanita, dan siger ini dijadikan sebagai identitas Lampung. Ada beragam siger di Lampung seperti siger dari Melinting, siger dari Abung, siger dari Pubian, siger dari Paksi Pak, dan sebagainya. Demikian pula dengan kain tapis yang merupakan kain tradisional identitas Lampung, kain ini hanya ada di daerah Lampung dan menjadi ikon Lampung.

\section{Tempat pertunjukan}

Tempat pertunjukan adalah tempat yang digunakan untuk mempergelarkan suatu pertunjukan atau pementasan. Tempat pertujukan dapat berupa panggung, yaitu tempat pertunjukan yang hanya dapat dilihat satu arah atau dari depan. Adapun bentuk-bentuk arena pertunjukan antara lain arena sentral, tapal kuda, dan setengah lingkaran (arena terbuka).

Tempat pertunjukan yang berbentuk arena sentral biasanya tempat yang digunakan untuk pentas yang berada di tengah penonton. Pada tempat pentas bentuk tapak kuda, penonton berada di depan, serta di samping kanan dan kiri tempat pertunjukan. Adapun bentuk setengah lingkaran (arena terbuka), antara penonton dengan tempat pertunjukan biasanya disekat oleh pembatas. Tari melinting dipentaskan di tempat upacara adat yang sedang berlangsung atau bisa juga di tempat pertunjukan lainnya, baik berupa panggung, arena sentral, tapal kuda maupun setengah lingkaran.

\section{PENUTUP}

Tari melinting merupakan salah satu jenis kesenian yang berasal dari daerah Melinting, dan bermula dari sebuah tarian sakral yang hanya ditampilkan di saat-saat tertentu saja. Namun saat ini tarian tersebut sudah banyak mengalami perubahan dan perkembangan. Tarian tersebut sudah tidak dianggap sakral lagi, sudah banyak modifikasi atau kreasi baru, serta ditampilkan dalam acara-acara resmi, ajang festival, maupun untuk penyambutan tamu kehormatan.

Tarian ini banyak mengandung filosofi yang mendasari kehidupan masyarakat Melinting, khususnya dalam kehidupan tradisinya. Kearifan tradisional masyarakat Melinting juga tercermin dari filosofi gerakan tarian yang ada. Seperti gerakan yang mengambil unsur flora maupun fauna yang ada di daerah tersebut.

\section{DAFTAR SUMBER}

Dana Arta, Wayan Sumerta. 2013. Gamolan Pekhing. Bandar Lampung: Sekelek Institute dan Publishing House.

Eko Wahyuningsih, I Made Giri Gunadi, Zanariah. Editor: Nyoman Maliani. 2009.

Katalog Topeng Lampung. Pemerintah Provinsi Lampung, Dinas Kebudayaan dan Pariwisata, UPTD Museum Negeri Provinsi Lampung "Ruwa Jurai".

Esther Helena Sinuraya, Asnan Sabirin, Eko Wahyuningsih. 2005.

Pakaian dan Upacara Adat Perkawinan Lampung Melinting. Dinas Pendidikan Provinsi Lampung UPTD Museum Negeri Provinsi Lampung“Ruwa Jurai”.

Holt, Claire. 2000.

Melacak Jejak Perkembangan Seni di Indonesia. Bandung: Arti.Line.

I Wayan Sumerta Dana Arta, Christian Heru Cahyo Saputro (editor). 2012. Gamolan Pekhing Musik Bambu dari Sekala Berak. Bandar Lampung: Sekelek Institute Publishing House.

Mustika, I Wayan, Indah Wigati, Putri Ika Lestari. 2011. 
Sekilas Budaya Lampung dan Seni Tari Pertunjukan Tradisionalnya. Bandar Lampung: Buana Cipta.

Mardihartono, Agus. 2013.

Kearifan Lokal dalam Pembangunan Daerah. Bandar Lampung: Indepth Publishing.

M. Arifin Nitipradjo Tegamoan. 2010.

Pergeseran Masyarakat Lampung dan Terbentuknya Marga-marga di

Lampung serta Struktur Sosial Masyarakat Lampung Pepadun dan Saibatin. Bandar Lampung: Mitra Media Pustaka.
Zainuddin, Bustami. 2011. "Mulang Tiuh". Bandar Lampung: Institut Studi Arus Informasi (ISAI).

Boekoe Adat Istiadat Lampung. Tertjitak oleh Toko \& Drukkerij LIE TEK LONG Pintu Besar No. 18 Batavia Telefoon No. 564.

Kuntara Raja Niti (naskah lama yang disalin pada tahun 1930). Milik Keratuan Melinting. 